DOI: 10.34015/2523-4552.2020.4.12

УДК 342.95 (477)

Рувін О. Г., кандидат юридичних наук, директор Київського науково-дослідного інституту судових експертиз Міністерства юстиції України ORCID: 0000-0003-0162-4686

\title{
ПОНЯТТЯ ТА ОЗНАКИ ГРОМАДСЬКОГО КОНТРОЛЮ ЗА ДІЯЛЬНІСТЮ СУДОВО-ЕКСПЕРТНИХ УСТАНОВ УКРАЇНИ
}

У статті наголошено, що здійснення громадського контролю за органами державної влади $є$ важливим чинником побудови громадянського суспільства. Він є одним із дієвих засобів забезпечення відкритості для суспільства діяльності державних інституцій. Незважаючи на те, що у нормативноправових актах безпосередньо вказується на громадський контроль, однак при цьому нині відсутнє чітке законодавче визначення поняття, а також форм здійснення громадського контролю.

Ключові слова: громадський контроль; форми контроль; правове регулювання; судово-експертні установи.

В статье отмечается, что осуществление общественного контроля за органами государственной власти является важным фактором построения гражданского общества. Он является одним из действенных средств обеспечения открытости для общества деятельности государственных институтов. Несмотря на то, что в нормативно-правовых актах непосредственно указывается на общественный контроль, однако при этом на сегодня отсутствует четкое законодательное определение понятия, а также форм осуществления общественного контроля.

Ключевые слова: общественный контроль; формы контроль; правовое регулирование; судебно-экспертные учреждения.

Постановка проблеми. Важливість забезпечення прозорості діяльності органів державної влади, органів місцевого самоврядування не піддається сумніву, адже відкритість інформації про таку діяльність $є$ одним із засобів забезпечення прав та свобод людини та громадянина, становлення громадянського суспільства в державі. Адже громадянське суспільство визначають як самоорганізовану й саморегульовану сферу публічно-правових відносин у дер- жаві, утворювану вільними і рівними індивідами та створеними ними об'єднаннями громадян, які функціонують, формуючи соціальний капітал та здійснюючи контроль за органами державної влади, служать підгрунтям демократії та визначальним чинником у розбудові правової держави [1, с. 150-151]. Отже, здійснення громадського контролю за органами державної влади є важливим чинником побудови громадянського суспільства. Він $є$ одним із дієвих 
засобів забезпечення відкритості для суспільства діяльності державних інституцій. Незважаючи на те, що у вищезазначених нормативно-правових актах безпосередньо вказується на громадський контроль, слід зазначити, що на сьогодні відсутнє чітке законодавче визначення поняття, а також форм здійснення громадського контролю.

Аналіз останніх досліджень і публікацій. Окремі проблемні питання, пов'язані із здійсненням громадського контролю у різних сферах суспільного життя у своїх наукових працях розглядали: В.Грохольський, С. Денисюк, С. Медведенко, О. Ігнатенко, А. Клочко, О.Клюєв, Ю. Ніронка, І. Сквірський, В. Собина, О. Терещук та багато інших. Втім, незважаючи на чималу кількість наукових розробок, в юридичній літературі фактично відсутні комплексні наукові дослідження, присвячені з'ясуванню сутності контролю за діяльністю судово-експертних установ України.

Постановка завдання. Метою статті $€$ з'ясування особливостей громадського контролю за діяльністю судово-експертних установ України. Для досягнення вказаної мети необхідно вирішити такі завдання: узагальнити наукові погляди вчених щодо тлумачення поняття «громадський контроль»; навести ключові ознаки даної наукової категорії, на основі чого сформувати авторський підхід до його тлумачення в розрізі представленої проблематики.

Наукова новизна дослідження полягає у тому, що наукова робота $€$ першою спробою на науковому рівні, спираючись на аналіз наукових поглядів вчених, запропонувати власне визначення поняття громадсько- го контролю за діяльністю судовоекспертних установ України.

Виклад основного матеріалу. Починаючи наукове дослідження доцільно акцентувати увагу на спробі законодавчого регулювання питань громадського контролю, яка мала місце через подання до Верховної Ради України проекту Закону «Про громадський контроль» народними депутатами Н.Королевською та Ю. Солод. Згідно цього законопроекту громадський контроль - це суспільна діяльність громадських об'єднань, предметом якої є здійснення нагляду за відповідністю діяльності органів державної влади, органів місцевого самоврядування, їх посадових і службових осіб Конституції України, законам України, іншим нормативноправовим актам та за дотриманням ними державної дисципліни. При цьому під державною дисципліною автори пропонують розуміти точне і неухильне дотримання об'єктами громадського контролю встановлених законодавством правил поведінки, діяльності, стосунків, посадових обов'язків, а також своєчасне і у повному обсязі виконання ними державних завдань і зобов'язань, в тому числі формування та витрачання бюджетів коштів [2].

Означений проект закону містить принципи, завдання, підстави здійснення громадського контролю, а також права, обов'язки, гарантії діяльності суб'єктів громадського контролю, до яких він відносить зареєстровані в установленому законом порядку громадські об'єднання, до мети діяльності яких статутом віднесено здійснення громадського контролю. Також проектом визначені види заходів громадського контролю: аналітичні і моніторингові 
дослідження діяльності об'єктів громадського контролю; громадська експертиза; перевірка. Доволі чітко проектом запропоновано регламентацію порядку проведення заходів громадського контролю, повноваження посадових осіб суб'єктів громадського контролю під час проведення таких заходів, надана характеристика актів реагування суб'єктів громадського контролю, зокрема, пропонується їх надання в п'ятиденний строк з дня завершення заходу громадського контролю керівнику чи іншій уповноваженій посадовій особі об'єкта громадського контролю або надсилання рекомендованим поштовим відправленням Зазначено, що акти реагування, якими зафіксовано факти виявлення порушень, що підпадають під ознаки кримінальних чи адміністративних правопорушень, мають надсилатися правоохоронним органам. Пропонований проект закону також визначав питання оскарження актів реагування та неправомірних дій уповноважених осіб суб'єктів громадського контролю, а також окреслював права органів виконавчої влади, органів місцевого самоврядування, їх посадових і службових осіб при проведенні громадського контролю [2].

Незважаючи на очевидну потребу в існуванні подібного нормативно-правового акту, цей проект закону так і не було прийнято.

У соціології громадський контроль розглядається як однин із видів соціального контролю, який здійснюється об'єднаннями громадян та самими громадянами. Він $є$ важливою формою реалізації демократії і способом залучення населення до управління суспільством та державою [3, с. 496].
У правовій літературі стосовно поняття та інших питань громадського контрою існують різноманітні підходи. Зокрема А. Клочко та В. Собина громадський контроль за діяльністю поліції розглядають як комплекс заходів, які здійснюються громадськістю (органами місцевого самоврядування, громадськими об'єднаннями, громадянами), що спрямовані на збирання, накопичення, аналіз інформації про діяльність працівників поліції, що, як результат, передбачає можливість та реальний механізм представлення цієї інформації до внутрішньовідомчого контролюючого органу 3 Національній поліції з метою усунення зазначених недоліків [4, с. 199]. С. Медведенко визначає громадський контроль як цілеспрямовану діяльність громадськості щодо нагляду за виконанням органами влади наданих їм повноважень, дотримання законності, дисципліни, прав і свобод людини. Автор справедливо підкреслює, що проблемою цього виду контролю $є$ те, що діяльність громадськості не можна назвати контролем у повному розумінні цього слова, тому що у процесі здійснення громадського контролю відсутня така ознака контролю, як право втручатися в оперативну діяльність та право притягати підконтрольного суб'єкта до юридичної відповідальності [5, с. 33].

Поняття «громадський контроль» О. Ігнатенко формулює як системну діяльність інститутів громадянського суспільства чи окремих громадян із метою вирішення суспільно-значущих завдань, захисту й забезпечення прав і свобод людини, задоволення потреб та інтересів суспільства в цілому, встановлення відповідності функціонування органів 
публічної влади вимогам законодавства у процесі їх соціальної взаємодії з громадськістю, що спрямована на забезпечення ефективності державно-громадських відносин. Громадський контроль $є$ властивістю суспільства і виступає в якості однієї з його основних функцій та у ролі індикатора визначення ефективності цього впливу. Він спрямований на оптимізацію діяльності публічної влади [6, c. 33].

На думку I. Сквірського, під громадським контролем слід розуміти спостереження громадськості за діяльністю органів державної влади та органів місцевого самоврядування, їх посадовими особами, а також за недержавними організаціями та іншими суб'єктами при здійсненні ними владних управлінських функцій, в тому числі і в разі виконання ними делегованих владних повноважень, яке має своєю метою забезпечення законності та дисципліни у сфері публічного управління [7, с. 24].

В. Грохольський розглядає громадський контроль як систему відносин громадянського суспільства з державою, яка базується на підзвітності органів державної виконавчої влади (Міністерство юстиції України, якому підпорядковані науково-дослідні установи судових експертиз) органам державної законодавчої влади (парламентський контроль) та недержавним структурам (громадськість). Основне спрямування громадського контролю над науково-дослідними установами запобігання необ'єктивності, упередженості, непрофесійності судових експертів під час дослідження процесів та явищ [8, с. 163]. Представляється некоректним віднесення парламентського контролю до громад- ського, оскільки парламентський контроль реалізується, хоча і через обраних громадськістю представників (народних депутатів України), проте парламентський контроль $€$ зовнішнім державним контролем, адже реалізується в межах встановлених законодавством повноважень окремою гілкою влади.

До форм громадського контролю науково-дослідних установ судових експертиз В.Грохольський відносить: звернення громадян, особистий прийом, а також громадську експертизу [8, с. 163]. На думку С. Денисюка, громадський контроль за адміністративною діяльністю правоохоронних органів являє собою сукупність дій суб'єктів контролю, врегульованих головним чином нормами права, що здійснюється на диспозитивних засадах, а наслідки мають рекомендаційний характер i полягають у перевірці законності адміністративної діяльності правоохоронних органів, їх посадових і службових осіб, стану дотримання прав, свобод фізичних та юридичних осіб під час застосування заходів адміністративного примусу, прийняття управлінських рішень, які стосуються забезпечення вказаних прав і свобод. До основних принципів громадського контролю автор відносить: верховенство права; об'єктивність, систематичність контрольної діяльності; дієвість, оперативність контролю; відкритість (прозорість) [9, c. 6-7].

Порівняно $з$ попереднім автором, С. Денисюк значного збільшує в своїй роботі форми громадського контролю, до яких він відносить: а) соціологічні та статистичні дослідження шляхом анкетування, опитування, стороннього нагляду, кон- 
тент-аналізу, фокус-групових дискусій тощо; б) громадська експертиза актів правоохоронних органів та їх проектів; в) публікації у $3 \mathrm{MI}$; г) включення представників громади до складу робочих груп, які утворюються владою; д) діяльність органів самоорганізації населення, громадських організацій; е) перевірка діяльності будь-якої організації або відповідальної особи, аналіз звітності, результатів діяльності з наступним вжиттям певних заходів щодо приведення цієї діяльності у відповідність до встановлених норм; ж) звернення громадян [9, с. 6-7]. Різноманіття названих форм громадського контролю обумовлюється як безпосереднім регулюванням окремих їх різновидів чинним законодавством (наприклад, звернення громадян), так і будь-якими іншими проявами діяльності громадян, які не $\epsilon$ забороненими законодавством. $\mathrm{y}$ зв'язку з цим слід підкреслити справедливість зауваження І. Сквірського про те, що оскільки суб'єктами громадського контролю виступають громадяни, то усі їх можливі дії або рішення щодо суб'єктів публічного управління можуть здійснюватися виключно у межах формули «дозволено усе, що прямо не заборонено законом». Проте дія названої формули подекуди може бути обмеженою. Це стосується насамперед сфери взаємовідносин приватних осіб із суб'єктами публічного управління. У даному випадку мова йде про те, що на дії (рішення) приватних осіб суб'єкти публічного управління можуть реагувати лише у межах закріпленої за ними компетенції, яка, фактично, і обмежує дію формули «дозволено усе, що прямо не заборонено законом». Таким чином, приватні особи можуть вступати у відносини із суб'єктами публічного управління лише у межах, визначених відповідними нормативними актами [10, c. 225].

До найважливіших рис досліджуваного громадського контролю 0. Терещук відносить такі [12, с. 85; 11]: 1) здійснюється специфічними суб'єктами: як індивідуальними (громадяни), так і колективними (громадські об'єднання, організації тощо); 2) суб'єкти громадського контролю виступають від імені громадськості, а не держави; 3) рішення суб'єктів громадського контролю носять, звичайно, рекомендаційний характер і мають здебільшого профілактичну направленість; 4) громадський контроль стосується фактично усіх напрямів діяльності правоохоронних органів у державі; 5) суб'єкти громадського контролю не мають права втручатися в оперативну діяльність підконтрольної структури (правоохоронні органи); 6) громадський контроль $€$ засобом запобігання порушень правоохоронних органів за допомогою засобів суспільного впливу (наприклад, громадські ради, мобільні громадські групи тощо); 7) громадський контроль за правоохоронною діяльністю має специфічні завдання та мету [12, с. 85].

Висновки. Отже, громадський контроль можна розглядати як певне соціально-правове явище, в основі якого лежить конституційний принцип відповідальності держави перед людиною за свою діяльність. Громадському контролю притаманна низка характерних рис, серед яких можна виділити: 1) здійснюється як окремими громадянами (в широкому значенні, включаючи громадян України, осіб без громадянства, іноземців, 
які на законних засадах перебувають на території держави), так і громадськими організаціями, які не включають органи публічної влади; 2) являє собою сукупність послідовних та взаємообумовлених дій; 3) здійснюється через встановлені законодавством форми, наприклад здійснення звернень та інші прямо не заборонені форми контролю; 4) метою громадського контролю $\epsilon$ встановлення відповідності об'єктивно існуючої діяльності публічних суб'єктів, зокрема судово-експертних установ, встановленим законодавством вимогам їх діяльності, виявлення та висвітлення можливих правопорушень та приведення такої діяльності до законодавчо визначеного правопорядку, у тому числі через звернення до уповноважених на державний примус органів та посадових осіб.

Таким чином, громадський контроль за діяльністю судовоекспертних установ слід тлумачити як діяльність громадських організацій та інших представників суспільс- тва, не об'єднаних у громадські організації, щодо взаємодії з органами державної влади, органами місцевого самоврядування, судовоекспертними установами та відповідними посадовими особами 3 приводу неухильного дотримання принципів законності, незалежності, об'єктивності і повноти експертного дослідження. Форми здійснення такого контролю встановлені чинним законодавством та мають загальний характер, серед них варто назвати: 1) ознайомлення з публічною інформацією; 2) громадська експертиза; 3) звернення; 4) проведення консультацій. Незважаючи на відсутність законодавчого визначення спеціальних форм контролю за діяльністю судово-експертних установ, доцільно наголосити, що названі форми мають не виключний характер, оскільки громадський контроль за діяльністю судово-експертних установ можна реалізовувати тими засобами, які не $\epsilon$ безпосередньо заборонені законодавством.

\section{Список використаних джерел}

1. Динник I. Сучасні тенденції змін взаємодії держави та громадянського суспільства в Україні. Публічне управління та публічна служба в Україні: стан проблем та перспективи розвитку: матеріали науково-практичної конференції за міжнародною участю (07-08 вересня 2018 р., м. Київ) / За заг. ред. В.С. Куйбіди, М. М. Білинської, В. Л. Федоренка. Київ : Видавництво Ліра-К, 2018. С. 149-151.

2. Про громадський контроль. Проекту Закону, внесений народними депутатами України Королевською Н. Ю. та Солод Ю. В. http://w1.c1.rada.gov.ua/ pls/zweb2/webproc34?id=\&pf3511=55101\&pf35401=341928 (дата звернення: 22.10.2020).

3. Соціологія: короткий енциклопедичний словник /за заг. ред. В. І. Воловича. Київ, 1998. 496 с.

4. Клочко А. М., Собина В. О. Громадський контроль за діяльністю поліції в Україні. Вісник Національного університету цивільного захисту України. Серія : Державне управління. 2017. Вип. 1. С. 194-201.

5. Медведенко С. В. Поняття та форми громадського контролю за діяльністю національної поліції України. Прикарпатський юридичний вісник. Вип. 2(27), 2019. C. 32-36. 
6. І Ігнатенко О. С. Теоретичні основи та розвиток громадського контролю в системі публічного управління. Держава та регіони. Серія: Державне управління. 2019. № 4 (68). С. 30-34.

7. Сквірський I. О. Поняття та основні ознаки громадського контролю в сучасній адміністративно-правовій доктрині Украӥни. Науковий вісник Ужгородського національного університету. Серія ПРАВО. Вип. 37. Т. 3. 2016. С. 23-24.

8. Грохольський В. П. Особливості громадського контролю за діяльністю науково-дослідних установ судових експертиз. Науковий вісник публічного та приватного права. 2016. Вип. 6. Т. 1. С. 161-164.

9. Денисюк С. Ф. Громадський контроль за правоохоронною діяльністю в Україні: адміністративно-правові засади. Автореф дис. докт. юрид наук. Дніпропетровськ. 2010. 36 с.

10. Сквірський I. Організаційні форми громадського контролю: сутність та зміст. Науковий вісник Ужгородського національного університету. Серія ПРАВО. 2013. Вип. 22. Ч. І. Т. 2. С. 223-227.

11. Ніронка Ю. Сутність громадського контролю за діяльністю органів публічної влади. Актуальні проблеми правознавства. 2019. Вип. 2 (18). С. 67-71.

12. Терещук О. Д. Адміністративно-правові засади громадського контролю за правоохоронною діяльністю в Україні: теорія і практика: монографія. Київ : ДП “Вид. дім “Персонал”, 2018. 460 с.

\section{References}

Dinnik, I. (2018). Suchasni tendenciyi zmin vzayemodiyi derzhavi ta gromadyanskogo suspilstva v Ukrayini. Publichne upravlinnya ta publichna sluzhba v Ukrayini: stan problem ta perspektivi rozvitku [Materiali naukovo-praktichnoyi konferenciyi za mizhnarodnoyu uchastyu (07-08 veresnya 2018 r., m. Kiyiv)] / Za zag. red. V. S. Kujbidi, M. M. Bilinskoyi, V. L. Fedorenka. Kiyiv : Vidavnictvo Lira-K, 149-151 [in Ukrainian].

Klochko, A. M., Sobina, V. O. (2017). Gromadskij kontrol za diyalnistyu policiyi v Ukrayini. Visnik Nacionalnogo universitetu civilnogo zahistu Ukrayini. Seriya : Derzhavne upravlinnya. Vip, 1, 194-201 [in Ukrainian].

Medvedenko, S. V. (2019). Ponyattya ta formi gromadskogo kontrolyu za diyalnistyu nacionalnoyi policiyi Ukrayini. Prikarpatskij yuridichnij visnik, 2(27), 32-36 [in Ukrainian].

Ignatenko, O. S. (2018). Teoretichni osnovi ta rozvitok gromadskogo kontrolyu v sistemi publichnogo upravlinnya. Derzhava ta regioni. Seriya: Derzhavne upravlinnya, 4 (68), 30-34 [in Ukrainian].

Skvirskij, I. O. (2016). Ponyattya ta osnovni oznaki gromadskogo kontrolyu v suchasnij administrativno-pravovij doktrini Ukrayini. Naukovij visnik Uzhgorodskogo nacionalnogo universitetu. Seriya PRAVO, 37 (3), 23-24 [in Ukrainian].

Groholskij, V. P. (2016). Osoblivosti gromadskogo kontrolyu za diyalnistyu naukovodoslidnih ustanov sudovih ekspertiz. Naukovij visnik publichnogo ta privatnogo prava, 6 (1), 161-164 [in Ukrainian].

Denisyuk, S. F. (2010). Gromadskij kontrol za pravoohoronnoyu diyalnistyu $v$ Ukrayini: administrativno-pravovi zasadi. (Avtoref. dis. dokt. yurid nauk.) Dnipropetrovsk [in Ukrainian].

Skvirskij, I. (2013). Organizacijni formi gromadskogo kontrolyu: sutnist ta zmist. Naukovij visnik Uzhgorodskogo nacionalnogo universitetu. Seriya PRAVO, 22 (I), 2, 223-227 [in Ukrainian].

Nironka, Yu. (2019). Sutnist gromadskogo kontrolyu za diyalnistyu organiv publichnoyi vladi. Aktualni problemi pravoznavstva, 2 (18), 67-71 [in Ukrainian]. 
Tereshuk, 0. D. (2018). Administrativno-pravovi zasadi gromadskogo kontrolyu za pravoohoronnoyu diyalnistyu v Ukrayini: teoriya i praktika: monografiya. Kiyiv : DP "Vid. dim "Personal" [in Ukrainian].

O. Ruvin, PhD, Director of the Kyiv Scientific Research Institute of Forensic Expertise of the Ministry of Justice of Ukraine

ORCID:0000-0003-0162-4686

\section{The concept and features of public control over the activities of forensic institutions of Ukraine}

It is emphasized that the exercise of public control over public authorities is an important factor in building civil society. It is one of the effective means of ensuring openness to society of state institutions. Despite the fact that the abovementioned regulations directly indicate public control, however, today there is no clear legislative definition of the concept and forms of public control.

It is substantiated that public control has a number of characteristics, among which are: 1) carried out both by individual citizens (in a broad sense, including citizens of Ukraine, stateless persons, foreigners who are legally on the territory of the state) and public organizations, which do not include public authorities; 2 ) is a set of consecutive and interdependent actions; 3 ) is carried out through the forms established by the legislation, for example, implementation of appeals and other directly not forbidden forms of control; 4) the purpose of public control is to establish compliance of objectively existing activities of public entities, including forensic institutions, the statutory requirements of their activities, detection and coverage of possible offenses and bringing such activities to the law, including through recourse to authorized bodies of state and officials.

It is proved that the forms of such control are established by the current legislation and have a general character, among them are named: 1) acquaintance with public information; 2) public examination; 3) treatment; 4) conducting consultations.

Keywords: public control; forms of control; legal regulation; forensic institutions. 